\title{
Physicians Attitude towards Pressure Injury Prevention and Management
}

\author{
Abdullah Bany Hamdan1*, Balaji Duraisamy1, Sherwynn Javison'1, Tariq Wani², Musa Alharbi1 \\ ${ }^{1}$ Comprehensive Cancer Center, King Fahad Medical City, Riyadh, KSA \\ ${ }^{2}$ Research Center, King Fahad Medical City, Riyadh, KSA \\ Email: ^ahamdan@kfmc.med.sa
}

How to cite this paper: Hamdan, A.B. Duraisamy, B., Javison, S., Wani, T. and Alharbi, M. (2020) Physicians Attitude towards Pressure Injury Prevention and Management. Journal of Cancer Therapy, 11, 189-198.

https://doi.org/10.4236/jct.2020.114016

Received: February 20, 2020

Accepted: April 4, 2020

Published: April 7, 2020

Copyright (C) 2020 by author(s) and Scientific Research Publishing Inc. This work is licensed under the Creative Commons Attribution International License (CC BY 4.0).

http://creativecommons.org/licenses/by/4.0/

\begin{abstract}
Background: Cancer and its management can cause cachexia, which, along with prolonged immobility could lead to the development of chronic pressure ulcers (PU). These complications result into infection and/or pressure injury. Though pressure injury related tasks, are deemed to be given to staff nurses alone. Little of literature is available on the physician's attitude towards PU prevention and management. Medical interns in 2015 concluded that $70 \%$ of them need more education in pressure injury. Present study is about physicians involved in pressure injury identification and management in a Cancer Center. Material and methods: A cross-sectional study was conducted in King Fahad Medical City among oncology physicians using self-administered 11 statement survey questionnaire. Physician residents, fellows, assistant consultants' and consultants' attitudes were compared. Statistical analyses were performed using SPSS. Results: In total 50 physicians completed the survey. The physicians demonstrated a positive attitude with an average mean score of $42.35 \pm 4.65(32,51)$. The difference in the attitude scores among sub-groups was not statistically significant. Conclusions: Our study demonstrated a positive attitude towards pressure ulcer prevention and management among physicians working in Cancer Center. We have also highlighted the challenges in maintaining this positive attitude and possible strategies for improvement in the future.
\end{abstract}

\section{Keywords}

Cancer, Oncology, Attitude, Physician, Pressure, Skin, Injury

\section{Introduction}

In most models of health care, the physician is considered to be the leader of the multidisciplinary team. Physicians are task-oriented, and their involvement in all 
areas of patient-care is certainly evident and remarkable. They act as mediators in initiating patient-centered healthcare goal(s) where patients are the core of the multidisciplinary team that plans and implements a care plan in a safe manner [1]. Cancer management has advanced a lot, and a majority of the patients attain cure or long term remissions. However, patients experience easy fatigability caused by systemic treatments such as chemotherapy and radiotherapy leading them to stay on a bed rather than to be active [2]. In addition, chemotherapy treatment can cause cachexia, also, prolong immobility, and can cause chronic wounds that would lead to complications such as infection and/or pressure injury [3] that would be a challenge for oncology physicians and nurses. Furthermore, the small proportion of patients who have progressive, incurable illness and the dying patients could acquire complex malignant ulcers along with pressure ulcers which need to be understood and anticipated in a person approaching end of life [4].

Pressure injury is a localized skin or tissue damage, usually in a prominent bony area caused by pressure, shear, dehydration, medication, underweight, malnutrition, low level of hemoglobin, and advanced age [5]. Pressure injury affects a vast majority of bedbound cancer patients because of its complex relationship with ongoing therapy and its impact on the physical, psychological, social and spiritual domains of care. In a global perspective, cytotoxic medications could hinder wound healing process which would lead to chronic wound(s) and even lead to greater mobility restrictions because of pain and discomfort.

Most physicians are not involved in pressure injury assessment and management, and all pressure injury related tasks are deemed to be dealt with staff nurses alone [6]. A study in the Netherlands on 16,344 patients in 89 healthcare institutions reported a mean pressure injury prevalence of $23.1 \%$ in a day which could cost hospital expenditures even higher estimated US\$350 million [7]. A conclusive evidence reported that only $48 \%$ of geriatric physicians correctly identified a particular risk assessment tool, $67 \%$ correctly identified the stage 1 , and $52 \%$ identified the stage 4 pressure injury descriptions respectively [6] [8]. Furthermore, a survey among medical interns (2015) concluded that $70 \%$ need more education in pressure injury [5]. Due to these reasons, pressure injury has become one of the major, preventable problems in almost all healthcare organizations. Although the majority of pressure injuries literature focused on nursing, there were limited references focused on physician and rarely on oncologists.

This study aims to determine the attitude of Cancer Center physicians toward pressure injury prevention and management.

\section{Methodology}

A cross sectional study was conducted in the Comprehensive Cancer Center of King Fahad Medical City among physicians in medical oncology, adult hematology, radiation oncology, palliative care, and pediatric hematology-oncology. It was conducted in 2018. 


\subsection{Study Population and Data Collection Procedure}

The eligible respondents were physician residents, fellows, assistant consultants and consultants working currently in the Comprehensive Cancer Center. Physicians who refused, on leave, and are not working in Cancer Center, were excluded from the study. A paper-based 11 statement survey questionnaire was distributed using convenient sampling technique during their sign-in/off meeting for two months.

\subsection{Study Instrument and Measure}

The validated survey tool from AHRQ's Views on Pressure Ulcer Prevention [9] was used in this study. The 11 statements of the survey questionnaire were in the original English language version. The respondents were asked to grade each statement using five-level measurement, $5=$ strongly agree, $4=$ agree, $3=$ neutral, 2 = disagree and $1=$ strongly disagree. In addition, the questionnaire comprised of affirmative $(1,6,7,11)$ and negative $(2,3,4,5,8,9,10)$ statements. The expected scores were in between 11 and 55 , thereby closer to 55 indicate more positive attitude.

\subsection{Sample Size and Statistical Analysis}

The estimated physician population working in the Comprehensive Cancer Center of King Fahad Medical City from medical oncology, adult hematology, radiation oncology, palliative care, and pediatric hematology-oncology is 100 . Presumably; $50 \%$ of physicians have prior education about the pressure injury identification and management in our Cancer Center. Therefore, based on a 95\% confidence interval, a $10.0 \%$ margin of error was established with $80 \%$ power to detect such a difference. An estimated sample of 50 was calculated by Cochran's method with the help of Rao Online Software (Raosoft, Inc. Seattle, WA). Those 50 physicians were recruited in this study through the convenience sampling procedure.

The data was presented as averages and percentages. The intergroup comparison among physician's attitude was analyzed by chi-square test, student's independent $\mathrm{t}$-test and F-test (ANOVA), using statistical package SPSS version 22. All the inferences were made at $95 \%$ confidence interval.

\subsection{Ethical Consideration}

Explanation of the study process, risks and benefits had presented to the respondents with an emphasis on confidentiality and the right to withdraw. Participation remained voluntary. The study was approved by the ethics committee (IRB) in King Fahad Medical City.

\section{Result}

A total of 50 physicians responded to the survey from the Cancer Center. Majority of the respondents were male (84\%), young 25 - 44 years old (86\%) and with 
total years of professional experience of $\geq 10$ years (46\%). Most of them had $<2$ years (46\%) experience in the Comprehensive Cancer Center and only $14 \%$ spent $\geq 10$ years. On the other hand, $50 \%$ of them had read an article in pressure injury within six months from the time of the survey. Most were postgraduates (72\%), working as assistant consultants (36\%), residents (30\%), fellows (18\%), and consultants (16\%) respectively. Table 1 (a) presents the social demographic characteristics of the respondents.

Table 1(b) shows the percentage distribution of responses to the individual items in the questionnaire. Questions 1, 6, 7 and 11 had been reverse scored.

The analysis of the physicians' responses to the questionnaire is in Table 2. The mean score of every question was calculated under each category of physicians and compared for least significant mean differences. The physician had an average mean score of $3.85+/-0.42(2.91,4.64)$. The mean sum of scores was $42.35+/-4.65(32,51)$. The total score as on evidence in the literature on evidence in the literature was distinguished into positive attitude $\geq 40$ and negative attitude $<40$ as binary outcome based. In summary, there is no significant difference in attitude across the various subgroups of physicians.

Table 3 demonstrates that there is no statistical difference in attitude towards pressure ulcer management based on differences in demographics, position, years of training or experience.

\section{Discussion}

Physician is the primary leader in patient-care, who has significant contribution and direct involvement in the care of pressure injury. Physician does unify treatment plan(s) with nursing and other concerned stakeholders. The physician must have the ability to streamline the knowledge across their borders and spread to the concerned teams. Cancer patients require extreme levels of resilience and compassionate care by all members of the multidisciplinary team including nurses and doctors. In view of palliative care, dying patients are incredibly exhausted, and self-care is dependent on others. Wound management is both curative and palliative intervention because any lacking in wound care may lead to discomfort that could affect the quality of dying [4]. Cancer patients are most likely to developed pressure injury, and physician participation would be needed. Oncologists who have full knowledge and capability to choose the most suitable, effective, and convenient medical intervention in pressure injury prevention and management must lead the quest to pressure injury prevention through multidisciplinary reinforcement and quality control for implementing the good clinical practice. Applied knowledge of physician influence belief and attitude of fellow care givers, that sustain with change in their mindset. We believe that active participation of primary physician would improve patient and family experience and would create a new gold standard of care in pressure injury management.

This study revealed that physicians in our Cancer Center had positive attitude for pressure ulcer prevention with total mean score of $42.35+/-4.65(32,51)$. 
Table 1. (a) Social demographic information; (b) Distribution of responses to the individual items.

(a)

\begin{tabular}{|c|c|c|}
\hline $\mathrm{n}=50$ & & $\mathrm{~F}(\%)$ \\
\hline \multirow{2}{*}{ Gender } & Male & $42(84 \%)$ \\
\hline & Female & $8(16 \%)$ \\
\hline \multirow{5}{*}{ Age } & $<25$ & $0(0 \%)$ \\
\hline & $25-34$ & $23(46 \%)$ \\
\hline & $35-44$ & $20(40 \%)$ \\
\hline & $\geq 45$ & $7(14 \%)$ \\
\hline & $<2$ & $4(8 \%)$ \\
\hline \multirow{4}{*}{ Total years of professional experience } & $\geq 2$ and $<5$ & $9(18 \%)$ \\
\hline & $\geq 5$ and $<10$ & $14(28 \%)$ \\
\hline & $\geq 10$ & $23(46 \%)$ \\
\hline & $<2$ & $23(46 \%)$ \\
\hline \multirow{3}{*}{ Years of experience in CCC } & $\geq 2$ and $<5$ & $14(28 \%)$ \\
\hline & $\geq 5$ and $<10$ & $6(12 \%)$ \\
\hline & $\geq 10$ & $7(14 \%)$ \\
\hline \multirow{4}{*}{$\begin{array}{l}\text { Last time you have read an article about } \\
\text { pressure injury }\end{array}$} & $<1$ month & $5(10 \%)$ \\
\hline & $1-6$ month & $6(12 \%)$ \\
\hline & $>6$ month & $25(50 \%)$ \\
\hline & Never & $14(28 \%)$ \\
\hline \multirow{3}{*}{ Physician's education level } & Intern & $0(0 \%)$ \\
\hline & Resident & $14(28 \%)$ \\
\hline & Postgraduate & $36(72 \%)$ \\
\hline \multirow{4}{*}{ Occupational category of physician } & Resident & $15(30 \%)$ \\
\hline & Fellow & $9(18 \%)$ \\
\hline & Asst. consultant & $18(36 \%)$ \\
\hline & Consultant & $8(16 \%)$ \\
\hline
\end{tabular}

(b)

1) All patients are at potential risk of developing pressure ulcers.

2) Pressure ulcer prevention is time-consuming for me to carry out.

Strongly agree

$$
\text { Agree }
$$

Neither agree nor disagree

$$
\text { Disagree }
$$

Strongly disagree

Strongly agree

$$
\text { Agree }
$$

Neither agree nor disagree

$$
\text { Disagree }
$$

trongly disagree
$6(12.0 \%)$

$21(42.0 \%)$

$8(16.0 \%)$

$15(30.0 \%)$

$0(0.0 \%)$

$1(2.0 \%)$

$9(18.0 \%)$

$7(14.0 \%)$

$25(50.0 \%)$

$8(16.0 \%)$ 


\section{Continued}

3) In my opinion, patients tend not to get as many pressure ulcers nowadays.

4) I do not need to concern myself with pressure ulcer prevention in my practice.

5) Pressure ulcer treatment is a greater priority than pressure ulcer prevention.

6) Continuous assessment of patients will give an accurate account of their pressure ulcer risk.

7) Most pressure ulcers can be avoided.

8) I am less interested in pressure ulcer prevention than other aspects of care.

9) My clinical judgment is better than any pressure ulcer risk assessment tool available to me.

10) In comparison with other areas of care pressure ulcer prevention is a low priority for me.

11) Pressure ulcer risk assessment should be regularly carried out on all patients during their stay in the hospital.

Average mean Score

$$
\text { Strongly agree }
$$

$2(4.0 \%)$

Agree

$20(40.0 \%)$

Neither agree nor disagree Disagree

Strongly disagree

Strongly agree

Agree

Neither agree nor disagree

$$
\text { Disagree }
$$

Strongly disagree

Strongly agree

$$
\text { Agree }
$$

Neither agree nor disagree

$$
\text { Disagree }
$$

Strongly disagree

Strongly agree

$$
\text { Agree }
$$

Neither agree nor disagree

$$
\text { Disagree }
$$

Strongly disagree

Strongly agree

$$
\text { Agree }
$$

Neither agree nor disagree

$$
\text { Disagree }
$$

Strongly disagree

Strongly agree

$$
\text { Agree }
$$

Neither agree nor disagree

$$
\text { Disagree }
$$

Strongly disagree

Strongly agree

$$
\text { Agree }
$$

Neither agree nor disagree

$$
\text { Disagree }
$$

Strongly disagree

Strongly agree

$$
\text { Agree }
$$

Neither agree nor disagree

$$
\text { Disagree }
$$

Strongly disagree

Strongly agree

$$
\text { Agree }
$$

Neither agree nor disagree

$$
\text { Disagree }
$$

Strongly disagree

Mean \pm SD

(min, $\max$ )
$9(18.0 \%)$

$14(28.0 \%)$

$5(10.0 \%)$

$3(6.0 \%)$

$0(0.0 \%)$

$3(6.0 \%)$

$24(48.0 \%)$

$20(40.0 \%)$

$2(4.0 \%)$

$3(6.0 \%)$

$1(2.0 \%)$

$26(52.0 \%)$

$18(36.0 \%)$

$21(42.0 \%)$

$28(56.0 \%)$

$1(2.0 \%)$

$0(0.0 \%)$

$0(0.0 \%)$

$22(44.0 \%)$

$25(50.0 \%)$

$2(4.0 \%)$

$1(2.0 \%)$

$0(0.0 \%)$

$3(6.0 \%)$

$4(8.0 \%)$

$9(18.0 \%)$

$23(46.0 \%)$

$11(22.0 \%)$

$3(6.0 \%)$

$4(8.0 \%)$

$18(36.0 \%)$

$22(44.0 \%)$

$3(6.0 \%)$

$0(0.0 \%)$

$3(6.0 \%)$

$3(6.0 \%)$

$35(70.0 \%)$

$9(18.0 \%)$

$21(42.0 \%$

$26(52.0 \%)$

$2(4.0 \%)$

$0(0.0 \%)$

$1(2.0 \%)$ $(2.91,4.64)$
$3.85 \pm 0.42$ 
Table 2. Mean response to each question.

\begin{tabular}{|c|c|c|c|c|c|}
\hline Mean $\pm \mathrm{SD}(\min , \max )$ & Resident & Fellow & $\begin{array}{c}\text { Asst. } \\
\text { Consultant }\end{array}$ & Consultant & Total \\
\hline $\begin{array}{l}\text { All patients are at } \\
\text { potential risk of } \\
\text { developing pressure } \\
\text { ulcers. }\end{array}$ & $\begin{array}{c}3.2 \pm 0.77 \\
(2,4)\end{array}$ & $\begin{array}{c}3.56 \pm 1.24 \\
(2,5)\end{array}$ & $\begin{array}{c}3.28 \pm 1.23 \\
(2,5)\end{array}$ & $\begin{array}{c}3.63 \pm 0.92 \\
(2,5)\end{array}$ & $\begin{array}{c}3.36 \pm 1.05 \\
(2,5)\end{array}$ \\
\hline $\begin{array}{l}\text { Pressure ulcer prevention } \\
\text { is time consuming for me } \\
\text { to carry out. }\end{array}$ & $\begin{array}{c}4 \pm 0.85 \\
(2,5)\end{array}$ & $\begin{array}{c}4 \pm 0.5 \\
(3,5)\end{array}$ & $\begin{array}{c}3.44 \pm 1.1 \\
(1,5)\end{array}$ & $\begin{array}{l}2.75 \pm 1.16 \\
(2,5)\end{array}$ & $\begin{array}{c}3.6 \pm 1.03 \\
(1,5)\end{array}$ \\
\hline $\begin{array}{l}\text { In my opinion, patients } \\
\text { tend not to get as many } \\
\text { pressure ulcers nowadays. }\end{array}$ & $\begin{array}{c}3.13 \pm 0.99 \\
(2,5)\end{array}$ & $\begin{array}{c}3 \pm 1.22 \\
(2,5)\end{array}$ & $\begin{array}{c}2.78 \pm 1.11 \\
\quad(1,5)\end{array}$ & $\begin{array}{c}3.25 \pm 1.39 \\
(2,5)\end{array}$ & $\begin{array}{c}3 \pm 1.12 \\
(1,5)\end{array}$ \\
\hline $\begin{array}{l}\text { I do not need to concern } \\
\text { myself with pressure ulcer } \\
\text { prevention in my } \\
\text { practice. }\end{array}$ & $\begin{array}{l}4.4 \pm 0.51 \\
\quad(4,5)\end{array}$ & $\begin{array}{c}4.44 \pm 0.88 \\
\quad(3,5)\end{array}$ & $\begin{array}{c}4 \pm 1.19 \\
(1,5)\end{array}$ & $\begin{array}{c}3.75 \pm 1.28 \\
(1,5)\end{array}$ & $\begin{array}{c}4.16 \pm 1 \\
(1,5)\end{array}$ \\
\hline $\begin{array}{l}\text { Pressure ulcer treatment } \\
\text { is a greater priority than } \\
\text { pressure ulcer prevention. }\end{array}$ & $\begin{array}{c}4.13 \pm 1.19 \\
(1,5)\end{array}$ & $\begin{array}{c}4.44 \pm 0.53 \\
(4,5)\end{array}$ & $\begin{array}{c}4 \pm 0.91 \\
(2,5)\end{array}$ & $\begin{array}{c}3.88 \pm 1.25 \\
(1,5)\end{array}$ & $\begin{array}{c}4.1 \pm 0.99 \\
(1,5)\end{array}$ \\
\hline $\begin{array}{l}\text { Continuous assessment of } \\
\text { patients will give an } \\
\text { accurate account of their } \\
\text { pressure ulcer risk. }\end{array}$ & $\begin{array}{c}4.47 \pm 0.52 \\
(4,5)\end{array}$ & $\begin{array}{c}4.33 \pm 0.71 \\
(3,5)\end{array}$ & $\begin{array}{c}4.44 \pm 0.51 \\
(4,5)\end{array}$ & $\begin{array}{c}4.25 \pm 0.46 \\
(4,5)\end{array}$ & $\begin{array}{c}4.4 \pm 0.53 \\
(3,5)\end{array}$ \\
\hline $\begin{array}{l}\text { Most pressure ulcers } \\
\text { can be avoided. }\end{array}$ & $\begin{array}{c}4.27 \pm 0.8 \\
(2,5)\end{array}$ & $\begin{array}{c}4.33 \pm 0.71 \\
(3,5)\end{array}$ & $\begin{array}{c}4.33 \pm 0.59 \\
(3,5)\end{array}$ & $\begin{array}{c}4.63 \pm 0.52 \\
(4,5)\end{array}$ & $\begin{array}{c}4.36 \pm 0.66 \\
(2,5)\end{array}$ \\
\hline $\begin{array}{l}\text { I am less interested in } \\
\text { pressure ulcer prevention } \\
\text { than other aspects of care. }\end{array}$ & $\begin{array}{c}3.67 \pm 0.98 \\
\quad(2,5)\end{array}$ & $\begin{array}{c}4 \pm 0.87 \\
(2,5)\end{array}$ & $\begin{array}{c}3.94 \pm 0.73 \\
(3,5)\end{array}$ & $\begin{array}{c}2.88 \pm 1.81 \\
\quad(1,5)\end{array}$ & $\begin{array}{c}3.7 \pm 1.09 \\
(1,5)\end{array}$ \\
\hline $\begin{array}{l}\text { My clinical judgment is } \\
\text { better than any pressure } \\
\text { ulcer risk assessment tool } \\
\text { available to me. }\end{array}$ & $\begin{array}{c}3.27 \pm 0.8 \\
(2,5)\end{array}$ & $\begin{array}{c}3.33 \pm 1 \\
(1,4)\end{array}$ & $\begin{array}{c}3.61 \pm 0.78 \\
(2,5)\end{array}$ & $\begin{array}{c}3 \pm 1.41 \\
(1,4)\end{array}$ & $\begin{array}{c}3.36 \pm 0.94 \\
(1,5)\end{array}$ \\
\hline $\begin{array}{l}\text { In comparison with other } \\
\text { areas of care, pressure } \\
\text { ulcer prevention is a low } \\
\text { priority for me. }\end{array}$ & $\begin{array}{c}4.07 \pm 0.46 \\
(3,5)\end{array}$ & $\begin{array}{c}4.22 \pm 0.44 \\
(4,5)\end{array}$ & $\begin{array}{c}4.11 \pm 0.47 \\
(3,5)\end{array}$ & $\begin{array}{c}3.38 \pm 1.3 \\
(2,5)\end{array}$ & $\begin{array}{c}4 \pm 0.7 \\
(2,5)\end{array}$ \\
\hline $\begin{array}{l}\text { Pressure ulcer risk } \\
\text { assessment should be } \\
\text { regularly carried out on } \\
\text { all patients during their } \\
\text { stay in hospital. }\end{array}$ & $\begin{array}{c}4.4 \pm 0.51 \\
(4,5)\end{array}$ & $\begin{array}{c}4.11 \pm 1.36 \\
(1,5)\end{array}$ & $\begin{array}{c}4.39 \pm 0.5 \\
(4,5)\end{array}$ & $\begin{array}{c}4.25 \pm 0.71 \\
(3,5)\end{array}$ & $\begin{array}{c}4.32 \pm 0.74 \\
(1,5)\end{array}$ \\
\hline $\begin{array}{l}\text { Average mean Score } \\
\text { (individual questions) }\end{array}$ & $\begin{array}{l}3.91 \pm 0.36 \\
(3.36,4.64)\end{array}$ & $\begin{array}{l}3.98 \pm 0.39 \\
(3.45,4.55)\end{array}$ & $\begin{array}{c}3.85 \pm 0.4 \\
(3.27,4.55)\end{array}$ & $\begin{array}{c}3.6 \pm 0.58 \\
(2.91,4.55)\end{array}$ & $\begin{array}{l}3.85 \pm 0.42 \\
(2.91,4.64)\end{array}$ \\
\hline Total mean Score & $\begin{array}{c}43 \pm 3.96 \\
(37,51)\end{array}$ & $\begin{array}{l}43.78 \pm 4.29 \\
(38,50)\end{array}$ & $\begin{array}{l}42.33 \pm 4.35 \\
\quad(36,50)\end{array}$ & $\begin{array}{c}39.63 \pm 6.37 \\
(32,50)\end{array}$ & $\begin{array}{l}42.36 \pm 4.65 \\
\quad(32,51)\end{array}$ \\
\hline
\end{tabular}


Table 3. Comparison of overall mean scores.

\begin{tabular}{|c|c|c|c|c|c|}
\hline \multicolumn{2}{|c|}{ Score cutoff 40} & $<40$ & $\geq 40$ & Total & $\mathrm{p}$-value \\
\hline \multirow[b]{2}{*}{ Gender } & Male & $11(26.2)$ & $31(73.8)$ & $42(84.0)$ & \multirow[b]{2}{*}{0.101} \\
\hline & Female & $0(0)$ & $8(100.0)$ & $8(16.0)$ & \\
\hline \multirow{4}{*}{ Age (yr.) } & $<25$ & $0(0)$ & $0(0)$ & $0(0)$ & \multirow{4}{*}{0.754} \\
\hline & $25-34$ & $4(17.4)$ & 19 (82.6) & $23(46.0)$ & \\
\hline & $35-44$ & $5(25.0)$ & $15(75.0)$ & $20(40.0)$ & \\
\hline & $\geq 45$ & $2(28.6)$ & $5(71.4)$ & $7(14.0)$ & \\
\hline \multirow{4}{*}{$\begin{array}{l}\text { Total years of } \\
\text { professional } \\
\text { experience }\end{array}$} & $<2$ & $0(0)$ & $4(100.0)$ & $4(8.0)$ & \multirow{4}{*}{0.207} \\
\hline & $\geq 2$ and $<5$ & $3(33.3)$ & $6(66.7)$ & $9(18.0)$ & \\
\hline & $\geq 5$ and $<10$ & $1(7.1)$ & $13(92.9)$ & $14(28.0)$ & \\
\hline & $\geq 10$ & $7(30.4)$ & $16(69.6)$ & $23(46.0)$ & \\
\hline \multirow{4}{*}{$\begin{array}{c}\text { Years of experience } \\
\text { in CCC }\end{array}$} & $<2$ & $6(26.1)$ & 17 (73.9) & $23(46.0)$ & \multirow{4}{*}{0.449} \\
\hline & $\geq 2$ and $<5$ & $1(7.1)$ & $13(92.9)$ & $14(28.0)$ & \\
\hline & $\geq 5$ and $<10$ & $2(33.3)$ & $4(66.7)$ & $6(12.0)$ & \\
\hline & $\geq 10$ & $2(28.6)$ & $5(71.4)$ & $7(14.0)$ & \\
\hline \multirow{4}{*}{$\begin{array}{c}\text { Last time you have } \\
\text { read an article about } \\
\text { PU }\end{array}$} & $<1$ month & $2(40.0)$ & $3(60.0)$ & $5(10.0)$ & \multirow{4}{*}{0.161} \\
\hline & $1-6$ month & $3(50.0)$ & $3(50.0)$ & $6(12.0)$ & \\
\hline & $>6$ month & $3(12.0)$ & $22(88.0)$ & $25(50.0)$ & \\
\hline & Never & $3(21.4)$ & $11(78.6)$ & $14(28.0)$ & \\
\hline \multirow{3}{*}{$\begin{array}{c}\text { Physician's } \\
\text { education level }\end{array}$} & Intern & $0(0)$ & $0(0)$ & $0(0)$ & \multirow{3}{*}{0.412} \\
\hline & Resident & $2(14.3)$ & $12(85.7)$ & $14(28.0)$ & \\
\hline & Post Graduate & $9(25.0)$ & $27(75.0)$ & $36(72.0)$ & \\
\hline \multirow{4}{*}{$\begin{array}{c}\text { Occupational } \\
\text { category of } \\
\text { physician }\end{array}$} & Resident & $3(20.0)$ & $12(80.0)$ & $15(30.0)$ & \multirow{4}{*}{0.693} \\
\hline & Fellow & $2(22.2)$ & $7(77.8)$ & $9(18.0)$ & \\
\hline & Asst. Consultant & $3(16.7)$ & $15(83.3)$ & $18(36.0)$ & \\
\hline & Consultant & $3(37.5)$ & $5(62.5)$ & $8(16.0)$ & \\
\hline
\end{tabular}

Similarly; Suen et al. in 2012 showed that interns and medical residents had a mean attitude scores of 43.8 and 38.8 respectively. This positive attitude among the physicians can be attributed to the high levels of quality standards, clinical audit, education and continuous monitoring of key performance indicators in our center for the prevention and management of pressure injuries. In a previous study done at this Cancer Center, 51.18\% of oncology nurses demonstrated a positive attitude towards pressure ulcer prevention [10].

Though positive knowledge and attitude does not necessarily translate in to positive practice, it is fair to assume that a negative attitude and knowledge will lead to poor clinical practice and outcome. As eluded to by Wong et al., prevalence of pressure ulcer could still be high in spite of positive perception of preventive measures [11]. 
We found no significant difference in attitude towards pressure ulcer prevention among physicians with various levels of experience (residents, interns, consultants etc.) and knowledge (last time when physician read an article on pressure ulcer). This means that continuous professional education regarding pressure ulcer prevention will definitely lead to further positive impact on knowledge, attitude and practice. Furthermore, educators and quality managers should include various modes of education of physicians, starting from medical school [12].

It is well known that the problem of high pressure ulcer prevalence is complex and multifactorial. So, the strategies for the prevention of pressure ulcer have to be multidimensional. Implementing a multi-pronged educational approach aimed at changing attitude and practice of physicians and health care professionals right from the early years of training in medical school through residency and post graduate program will be very effective.

One of the major challenges in maintaining a positive attitude of physicians and health care professionals is the lack of communication and engagement by the patients and their families regarding the risk, prevention and management of pressure injury. So, an important strategy is educating and engaging the patients and their families, empowering them to report PU symptoms to their physicians and to be actively involved in the care plan.

\section{Limitations}

In this due course, attitudes, knowledge, and practices need not be aligned positively. We have to correlate the results of this study with the day to day practice of physicians through a clinical audit. This study did not assess the knowledge regarding pressure ulcer prevention and management strategies among physicians.

\section{Conclusions}

Studies on the attitude of physicians in pressure ulcer prevention are limited. This study is essential and documents the current views of the physicians in our center, which can serve as standards for improvement in the future through continuous professional education, training, and competency.

Our study demonstrated a positive attitude towards pressure ulcer prevention and management among physicians working in Cancer Center. We have also highlighted the challenges in maintaining this positive attitude and possible strategies for improvement in the future.

\section{Conflicts of Interest}

The authors declared no conflicts of interest.

\section{References}

[1] Care PC (2010) Patient-Centered Care. Ontario Medical review. 
[2] Dimeo, F.C., Stieglitz, R.D., Novelli-Fischer, U., Fetscher, S. and Keul, J. (1999) Effects of Physical Activity on the Fatigue and Psychologic Status of Cancer Patients during Chemotherapy. Cancer, 85, 2273-2277. https://doi.org/10.1002/(SICI)1097-0142(19990515)85:10<2273::AID-CNCR24>3.0. CO;2-B

[3] Ferris, F.D., Al Khateib, A.A., Fromantin, I., Hoplamazian, L., Hurd, T., Krasner, D.L., Maida, V., Price, P. and Rich-Vanderbij, L. (2007) Palliative Wound Care: Managing Chronic Wounds Across Life's Continuum: A Consensus Statement from the International Palliative Wound Care Initiative. Journal of Palliative Medicine, 10, 37-39. https://doi.org/10.1089/jpm.2006.9994

[4] Hughes, R,G,, Bakos, A.D., O’Mara, A. and Kovner, C.T. (2005) Palliative Wound Care at the End of Life. Home Health Care Management \& Practice, 17, 196-202. https://doi.org/10.1177/1084822304271815

[5] Hosseinzadeh, K. (2016) Medical Students Attitude towards Pressure Ulcer: A Cross Sectional Study from Iran. IOSR Journal of Nursing and Health Science, 5, 44-47.

[6] Levine, J.M., Ayello, E.A., Zulkowski, K.M. and Fogel, J. (2012) Pressure Ulcer Knowledge in Medical Residents: An Opportunity for Improvement. Advances in skin \& Wound Care, 25, 115-117. https://doi.org/10.1097/01.ASW.0000412908.43335.46

[7] Bours, G.J., Halfens, R.J., Abu-Saad, H.H. and Grol, R.T. (2002) Prevalence, Prevention, and Treatment of Pressure Ulcers: Descriptive Study in 89 Institutions in the Netherlands. Research in Nursing \& Health, 25, 99-110. https://doi.org/10.1002/nur.10025

[8] Suen, W., Parker, V.A., Harney, L., Nevin, S., Jansen, J., Alexander, L. and Berlowitz, D. (2012) Internal Medicine Interns' and Residents' Pressure Ulcer Prevention and Assessment Attitudes and Abilities: Results of an Exploratory Study. Ostomy Wound Management, 58, 28-35.

[9] Berlowitz, D.V., VanDeusen Lukas, C., Parker, V., Niederhauser, A., Silver, J., Logan, C. and Ayello, E. (2011) Preventing Pressure Ulcers in Hospitals: A Toolkit for Improving Quality of Care. Agency for Healthcare Research and Quality, Rockville, MD.

[10] Hamdan, A.B., Javison, S., Tamani, J., Sashidharan, S., Yahya, O.M., et al. (2018) Oncology Nurses' Beliefs, Attitudes, Perceived Barriers towards Pressure Ulcer Prevention. Journal of Health Education Research \& Development, 6, 278. https://doi.org/10.4172/2380-5439.1000278

[11] Wong, A.L., Walia, G.S., Bello, R., Aquino, C.S. and Sacks, J.M. (2018) Pressure Ulcer Prevalence and Perceptions on Prevention: A Hospital-Wide Survey of Health Professionals. Journal of Wound Care, 27, S29-S35. https://doi.org/10.12968/jowc.2018.27.Sup4.S29

[12] McCluskey, A. (2003) Occupational Therapists Report a Low Level of Knowledge, Skill and Involvement in Evidence-Based Practice. Australian Occupational Therapy Journal, 50, 3-12. https://doi.org/10.1046/j.1440-1630.2003.00303.x 